\title{
З ДОСВІДУ ВПРОВАДЖЕННЯ КРЕДИТНО-МОДУЛЬНОЇ СИСТЕМИ ОРГАНІЗАЦІЇ НАВЧАЛЬНОГО ПРОЦЕСУ В ІВАНО-ФРАНКІВСЬКОМУ НАЦОНАЛЬНОМУ МЕДИЧНОМУ УНІВЕРСИТЕТІ
}

\author{
М. М. Рожко, Г. М. Ерстенюк, В. В. Капечук, М. О. Іванців \\ ДВНЗ “Івано-Франківський національний медичний університет”
}

\section{THE EXPERIENCE OF INRODUCTION OF CREDIT-MODULAR SYSTEM OF EDUCATIONAL PROCESS IN IVANO-FRANKIVSK NATIONAL MEDICAL UNIVERSITY}

\author{
M. M. Rozhko, H. M. Erstenuyk, V. V. Kapechuk, M. O. Ivantsiv \\ SHEI "Ivano-Frankivsk National Medical University"
}

\begin{abstract}
Проведено систематизацію досвіду інтеграції кредитно-модульної системи організації навчального процесу в ІФНМУ, оцінено переваги засад Болонського процесу та розглянуто деякі проблемні аспекти.

3 метою координації роботи кураторів ECTS факультетів, деканатів, кафедр університету в руслі впровадження засад Болонського процесу, сдиних підходів та стандартів надання освітніх послуг студентам, системного моніторингу якості освіти в університеті створено відділ ЕСТS. Процес впровадження кредитно-модульної системи організації навчального процесу в університеті супроводжувався певними труднощами, які зумовлені передусім недосконалістю нормативноправової бази. Аналіз семирічного досвіду впровадження кредитно-модульної системи в університеті оцінюємо позитивно, оскільки покращилась мотивація студента до оволодіння знаннями та навичками.
\end{abstract}

Systematization of the first experience of integration of the credit-modular system of educational process organization is conducted in IFNMU, advantages of Bologna process are estimated and some problem aspects are considered.

In order to coordinate the work of the curators of all departments, dean's offices and university departments in implementing the principles of the Bologna process, common approaches and standards of educational services to students, system monitoring of educational quality at the University of the department of ECTS. The process of introduction of credit-modular system of educational process at the university was accompanied by certain difficulties caused primarily imperfection of the legal framework. Analysis of the seven-year experience of the credit-modular system at the university in general estimate is positive, as improved motivation of students to master knowledge and skills.

Вступ. Сучасна світова спільнота живе в умовах глобалізації та інтеграції, що проявляються у політичному, економічному, соціальному і культурному житті багатьох країн, при цьому досить актуальною постає проблема формування єдиного загальноосвітнього простору. Прикладом цього явища на європейському рівні є Болонський процес. Розвиток і вдосконалення системи вищої медичної освіти України, відповідно до вимог сьогодення, тісно пов'язані з упровадженням кредитно-модульної системи організації навчального процесу (КМСОНП) і забезпеченням інтеграції України у світовий науковий та освітянський простір.

Основна частина. 3 часу впровадження КМСОНП у ВМНЗ України, як і на медичному факультеті ІФНМУ, минуло 7 років. За цей час в університеті проведено велику роботу з упровадження вимог Болонського процесу, який 32010 р. поширюється на інших факультетах, зокрема стоматологічному та фармацевтичному. Переорієнтація методології навчального процесу та оцінювання знань студентів із лекційно-інформативної на індивідуально-диференційовану та особистісно-орієнтовану систему відбулась не тільки серед викладачів кафедр, але і студентів.

3 метою координації роботи кураторів ECTS усіх факультетів, деканатів та кафедр університету в руслі впровадження засад Болонського процесу, єдиних підходів та стандартів якості надання освітніх послуг студентам, а також для системного моніторингу в університеті створено відділ ECTS.

Аналіз семирічного впровадження кредитно-модульної системи організації навчального процесу на медичному факультеті свідчить про ії позитивну оцінку студентами та професорсько-викладацьким складом.

Поряд із цим вважаємо за необхідне зупинитися на деяких проблемних питаннях. Процес впроваджен-

(c) М. М. Рожко, Г. М. Ерстенюк, В. В. Капечук, М. О. Іванців 
ня кредитно-модульної системи організації навчального процесу в університеті, впродовж семи років, супроводжувався певними труднощами, які зумовлені передусім недосконалістю нормативно-правової бази. Ми все ще керуємось Тимчасовим положенням про КМСОНП у вищих медичних (фармацевтичних) навчальних закладах III-IV рівнів акредитації. Актуальним залишається питання своєчасного забезпечення типовими навчальними програмами дисциплін, зокрема студентів стоматологічного та фармацевтичного факультетів. Наявна розбіжність між типовими навчальними планами 3 підготовки фахівців кваліфікації “Лікар” та "Провізор”, зокрема в системі розрахунку трудомісткості навчального навантаження студента. Зокрема, для спеціальностей "Лікувальна справа", “Педіатрія" та "Стоматологія” 1 кредит дорівнює 30 год, а для спеціальності “Фармація" - 36 год. Тижневе аудиторне навантаження студента для всіх спеціальностей становить приблизно 30 навчальних годин.

Аналіз типових навчальних програм дисциплін показав розбіжності в системі оцінювання знань та вмінь студентів, для спеціальності “Фармація” це 100бальна система, хоча в цілому в галузі вищої медичної освіти в Україні прийнято 200-бальну систему.

Типовими навчальними програмами на перехідний період впровадження КМСОНП було запропоновано використання подвійної системи оцінювання рівня знань: поряд з багатобальною системою застосовували традиційну оцінку. Перший досвід викладання за кредитно-модульною системою показав недосконалість такої подвійної системи оцінювання, оскільки традиційна оцінка поточної успішності одразу ж конвертується в багатобальну систему, допуск до складання підсумкового модульного контролю (ПМК), оцінка ПМК, оцінка за дисципліну, ранжування - проводиться за багатобальною системою. Студент втрачає проміжні бали, якими за традиційного оцінювання просто знехтувано, а викладач змушений витрачати час на перерахунок традиційної оцінки в багатобальну. При цьому слід дати відповідь на запитання, чи справді механічний перерахунок традиційної оцінки в бали відповідає засадам багатобальної системи оцінювання рівня знань згідно з вимогами Болонського процесу.

Відповідь дає педагогічний експеримент, який проводили на кафедрі біологічної та медичної хімії університету впродовж 3-х років. Згідно з розробленими критеріями, відповідно до типової навчальної програми, студентів на поточних заняттях оцінювали тільки 3 використанням багатобальної шкали-від 1 до 11 балів, наприклад 3 дисципліни “Медична хімія”. Експеримент дав позитивний результат та був підтриманий студентами, які показали активну мотивацію та жваву зацікавленість підвищенням поточної успішності як складової кінцевого результату. За результатами проведеного експерименту підготовлено рекомендації, які підтримані центральною методичною комісією та вченою радою університету, рекомендовано до впровадження однієї (багатобальної) системи оцінювання на всіх кафедрах університету. На сьогодні в типових програмах окремих дисциплін у системі оцінювання ще зберігається прив'язка багатобальної оцінки поточної успішності студента до традиційної п'ятибальної системи, що унеможливлює більш об' єктивне оцінювання виявлених знань студентів.

Важливим є питання щодо організації навчального процесу за умов, коли дисципліни вивчають впродовж кількох курсів, наприклад "Внутрішня медицина", “Анатомія людини”, “Дитяча стоматологія” та ін. На вивчення цих дисциплін навчальними планами передбачена достатня кількість годин, при цьому навчальний матеріал структурований на незначну кількість модулів, що призводить до великої кількості практичних занять у модулі й низького, часто не більшого ніж 3 бали, максимального бала за заняття. Це, у свою чергу, зумовлює низьку мінімальну суму балів з поточної успішності, яка необхідна для допуску до ПМК (близько 33 \%). Вирішення даного питання можливе лише за умов прийняття спільного рішення з профільними опорними кафедрами.

Для студентів-медиків важливо не тільки осмислити і засвоїти отриману інформацію, але й оволодіти способами іiї практичного застосування і прийняття рішень. Поряд із стандартизованим тестовим контролем в університеті велику увагу звертають на практичну підготовку майбутніх фахівців. У навчальному процесі широко використовують методи інтерактивного навчання, обладнано спеціальні навчальні класи на базі кафедр та відділу інформаційно-аналітичного забезпечення університету. Важливу роль в оволодінні практичними навичками відіграє створений в університеті навчально-практичний центр. До його складу входять: клас інтерактивного навчання на кафедрі оперативної хірургії і топографічної анатоміі, 4 фантомних класи на стоматологічному факультеті, клас ін'єкційної техніки на кафедрі внутрішньої медицини № 4, підстанція швидкої допомоги, що дозволяє студентам працювати і в позааудиторний час. При проведенні підсумкового модульного контролю під час вивчення як фундаментальних, так i клінічних дисциплін велику увагу приділяють оволо- 
дінню студентами практичними навичками. 3 огляду на це, в типові навчальні програми, на нашу думку, варто внести зміни щодо кількості годин, відведених на приймання підсумкового модульного контролю з урахуванням часу для перевірки як теоретичних знань студентів, так і практичних навичок.

Аналіз навчальних програм клінічних дисциплін показав, що в ряду дисциплін відсутній важливий елемент практичної підготовки майбутнього лікаря написання історії хвороби (як правило, винесений у розділ самостійної позааудиторної роботи студента). На нашу думку, написання та захист історії хвороби необхідно включити або як окреме практичне заняття, або в підсумковий модульний контроль з відповідною бальною оцінкою праці студента.

Ще однією важливою проблемою є організація ПМК у кінці весняного семестру, оскільки збігаються в часі підсумкові модульні контролі з двох-трьох, a то і більше дисциплін, що призводить до низьких

\section{Література}

1. Підаєв А. В. Болонський процес в Свропі / А. В. Підаєв, В. Г. Передерій. -Київ, 2004. - 192 с.

2. Про затвердження Програми дій щодо реалізації положень Болонської декларації в системі вищої освіти і науки України на 2004-2005 роки : наказ МОН України № 49 від 23.01.2004p.

3. Про експериментальне впровадження кредитно-модульної системи організації навчального процесу у вищих медичних (фармацевтичних) навчальних закладах III-IV рівнів акредитації у 2004-2010 pр. : наказ МОЗ України № 685 від 31.12.2004 p.

4. Навчальний план підготовки фахівців освітньо-кваліфікаційного рівня “спеціаліст” кваліфікації “лікар” у ВНЗ IV результатів, морального виснаження студентів тощо. Ректорат університету для вирішення даної проблеми та 3 метою належної підготовки студентів до підсумкових модульних контролів ввів двотижневий відкоригований розклад занять, в якому щоденно підлягає контролю одна дисципліна (протягом останніх двох тижнів весняного семестру).

Узагальнюючи перші результати впровадження кредитно-модульної системи організації навчального процесу, можна зробити такі висновки:

1. Застосування принципів КМСОНП сприяє підвищенню мотивації студентів до оволодіння знаннями та практичними навичками як під час навчальних занять, так і при самостійній позааудиторній роботі.

2. 3 метою адаптації ідей ЕCTS до системи вищої медичної освіти України необхідно працювати над вдосконаленням нормативно-правової та матеріально-технічної бази забезпечення навчальної та наукової діяльності студентів.

рівня акредитації за спеціальностями 7.110101 “Лікувальна справа", 7.110104 “Педіатрія" (2007,2010 pp.).

5. Навчальний план підготовки фахівців освітньо-кваліфікаційного рівня “спеціаліст” кваліфікації “лікар-стоматолог” у ВНЗ IV рівня акредитації за спеціальністю 7.110106 “Стоматологія” (2007, 2010 pp.).

6. Навчальний план підготовки фахівців освітньо-кваліфікаційного рівня “спеціаліст” кваліфікації “провізор” у ВН3 IV рівня акредитації за спеціальністю 7.110201 “Фармація” (2007, 2010pp.).

7. Болюбаш Я. Я. Організація навчального процесу у вищих закладах освіти : навч. посіб. / Я. Я. Болюбаш.-К. : ВВП “Компас”, 1997.-64 с. 